\title{
Female genital mutilation/cutting: Knowledge, practice and experiences of secondary schoolteachers in North Central Nigeria
}

\author{
A S Adeniran, ${ }^{1}$ FWACS; FMCOG; A A Fawole,,${ }^{1}$ FWACS; O R Balogun, ${ }^{1}$ FWACS; M A Ijaiya, ${ }^{1}$ FWACS; \\ K T Adesina, ${ }^{1}$ FWACS, FMCOG; I P Adeniran, ${ }^{2}$ RN, RPN \\ ${ }^{1}$ Department of Obstetrics and Gynaecology, University of Ilorin and University of Ilorin Teaching Hospital, Ilorin, Nigeria
${ }^{2}$ In-service Education Unit, Nursing Services Department, University of Ilorin Teaching Hospital, Ilorin, Nigeria
}

Corresponding author: A S Adeniran (acrowncord@hotmail.com)

Background. Despite global efforts at eradicating female genital mutilation/cutting (FGM/C), the act continues to be performed globally. Objective. To determine the experience of schoolteachers about FGM/C and their possible role in contributing to its eradication. Methods. A prospective cross-sectional survey involving secondary schoolteachers from 18 secondary schools in Ilorin, North Central Nigeria, was undertaken during October and November 2014. All consenting participants completed a self-administered questionnaire on FGM/C. Statistical analysis was with SPSS version 20.0 with $\chi^{2}$ and logistic regression; a $p$-value of $<0.05$ was considered significant. Results. There were 371 participants (113 males (30.5\%) and 258 females (69.5\%)). More females than males were aware of FGM/C (205 v. 94; $\left.\chi^{2} 41.2 ; p=0.001\right) ; 180$ women $(69.8 \%)$ and 81 men $(71.7 \%)$ wanted awareness and the implications of FGM/C to be taught in schools, while 46 women (17.8\%) and 23 men (20.4\%) had previously educated students about FGM/C. Also, 109 (42.3\%) of the female teachers had been mutilated (mean (standard deviation) age 4.76 (4.86) years), and 49 mutilations (45.0\%) had been performed by traditional circumcisers. Of the teachers, $44.0 \%$ of men and $24.5 \%$ of women had subjected their daughters to FGM/C ( $p=0.029)$, mostly for religious reasons. The men initiated the majority of their daughters' mutilations, while the mothers-in-law were the main initiators among the women; $44(17.0 \%)$ women and $23(20.4 \%)$ men held the opinion that females should be circumcised, while the majority considered education and legislation to be the most important interventions to encourage its eradication. Predictors of the likelihood to support discontinuation of FGM/C include awareness of government policy about FGM/C and having a mutilated daughter. Conclusion. Education, reorientation and motivation of teachers will position them as agents for eradicating FGM/C.

S Afr J Obstet Gynaecol 2015;21(2):39-43. DOI:10.7196.SAJOG.1047

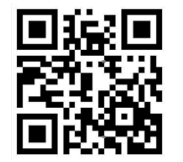

Female genital mutilation/cutting (FGM/C), also called female circumcision, is an old practice that reflects human rights abuse with potential for medical complications. ${ }^{[1]}$ This has triggered efforts aimed at its eradication at international, national and community levels. However, it remains endemic in about 29 countries in Africa, the Middle East and Asia. Recent reviews identified advocacy (including education, information and advocacy tools to encourage local, national and international efforts), research and guidelines for health systems about treatment and counselling of mutilated women as pertinent. ${ }^{[2]}$ Education and creating awareness have been identified as instrumental in the change of attitudes to support efforts at eradication of FGM/C. ${ }^{[3]}$

Students are generally exposed to information and learning at school; this provides an avenue to provide information and education about FGM/C to potential future parents who will need to make decisions about their children and FGM/C. Equipping them with pertinent information will be a great advantage, creating an increased probability for making decisions against FGM/C later in life. In order to achieve this, the level of knowledge, views, attitudes and experience of the schoolteachers who would be entrusted with this responsibility need to be evaluated. This will determine the approach towards their ability to fulfil the vital role of providing education that will stimulate a behaviour change in favour of discontinuation of FGM/C.

\section{Methods}

The study was a cross-sectional survey conducted among schoolteachers in 18 secondary schools in Ilorin, North Central Nigeria, during October and November 2014. A list of all secondary schools (public and private) was obtained from the Ministry of Education, and 18 institutions comprising equal numbers of public and private schools were selected by multistaged sampling with equal distribution in both rural and urban areas. All teachers were informed about the study, and consenting individuals were recruited using purposeful sampling. Each participant was requested to complete a self-administered questionnaire consisting of open- and closed-ended questions evaluating knowledge of, views on, attitudes towards and experience of FGM/C. Non-teaching members of staff at the institutions and teachers who declined participation were excluded from the study.

Assessment of the correct definition of FGM/C was defined as the ability to recognise it as the removal of part or whole of the female external genitalia without a medical reason or disease. ${ }^{[1-3]}$

The sample size was calculated using a previously described formula $^{[4]}$ and was based on the reported prevalence of FGM/C among Nigerian women (25\%), ${ }^{[5]}$ a confidence level of $95 \%$, a degree of accuracy of 0.05 and an estimated attrition rate of $10 \%$, giving a minimum sample size of 379 .

The information collected included demographic parameters, personal experience of female teachers about FGM/C, i.e. whether women had been mutilated or not, and the events surrounding the experience. All participants were asked about their experience regarding the mutilation of their daughters and the associated events, their view about teaching on awareness and implications of FGM/C in schools, current government policy and discontinuation of FGM/C. 
Participants' confidentiality was maintained by using codes instead of names and allowing only the research team access to the data.

Statistical analysis was done using SPSS version 20.0 (IBM, USA). The results were expressed in tables with percentages, Pearson's $\chi^{2}$ was used for comparison with calculation of odds ratios (ORs) at the $95 \%$ confidence interval (CI), and logistic regression; a $p$-value of $<0.05$ was considered significant.

Approval was obtained from the ethical review committee of the University of Ilorin Teaching Hospital, Ilorin, and the Kwara State Ministry of Education and Human Capital Development before commencement of the study.

\section{Results}

There were 371 participants in the study, with 113 (30.5\%) male (mean (standard deviation (SD)) age 34.90 (10.59) years; range $20-65)$ and 258 (69.5\%) female teachers (mean (SD) age $36.30 \quad(10.27)$ years; range 20 - 60). Of these, 69 males (61.1\%) and 175 females (67.8\%) were married, 44 males (38.9\%) and 77 females $(29.8 \%)$ were single, and 6 women $(2.5 \%)$ were widowed.

Table 1 shows that more females than males had heard about FGM/C (205 v. 94; $p=0.001$ ), and that compared with males they had heard about it earlier (mean (SD) age 14.27 (6.69) v. 15.31 (7.0) years; $t=1.229$;
Table 1. Knowledge of FGM/C among participants

\begin{tabular}{|c|c|c|c|c|}
\hline Variables & Male & Female & $t / \chi^{2}$ & $p$-value \\
\hline \multicolumn{5}{|l|}{ Heard about FGM, $n(\%)$} \\
\hline Yes & $94(83.2)$ & $205(79.5)$ & 41.207 & $<0.001$ \\
\hline No & $19(16.8)$ & $53(20.5)$ & 16.056 & $<0.001$ \\
\hline Age heard about FGM/C (years), mean (SD) & $15.31(7.00)$ & $14.27(6.69)$ & 1.229 & 0.220 \\
\hline \multicolumn{5}{|l|}{ Source of information, $n(\%)$} \\
\hline Radio & $27(23.9)$ & $27(10.5)$ & 0.000 & 1.000 \\
\hline TV & $14(12.4)$ & $25(9.7)$ & 3.103 & 0.078 \\
\hline My parents & $60(53.1)$ & $145(56.2)$ & 35.244 & $<0.001$ \\
\hline My teachers & $21(18.6)$ & $25(9.7)$ & 0.348 & 0.555 \\
\hline My friends & $14(12.4)$ & $41(15.9)$ & 13.255 & $<0.001$ \\
\hline Book & $21(18.6)$ & $27(10.5)$ & 0.750 & 0.386 \\
\hline Poster & $10(8.8)$ & $10(3.9)$ & 0.000 & 1.000 \\
\hline \multicolumn{5}{|l|}{ Definition of FGM/C, $n(\%)$} \\
\hline Correct & $81(71.7)$ & $199(77.1)$ & 49.729 & $<0.001$ \\
\hline Wrong & $20(17.7)$ & $38(14.7)$ & 5.586 & 0.018 \\
\hline Do not know & $12(10.6)$ & $21(8.1)$ & 2.455 & 0.117 \\
\hline \multicolumn{5}{|l|}{ Educated on FGM/C as a student } \\
\hline Yes & $37(32.7)$ & $80(31.0)$ & 15.803 & $<0.001$ \\
\hline No & $76(67.3)$ & $178(69.0)$ & 40.961 & $<0.001$ \\
\hline \multicolumn{5}{|l|}{ Education level when educated, $n(\%)$} \\
\hline Primary & $10(8.8)$ & $23(8.9)$ & 5.121 & 0.023 \\
\hline Secondary & $20(17.7)$ & $44(17.1)$ & 9.000 & 0.002 \\
\hline Tertiary & $7(6.2)$ & $13(5.0)$ & 1.800 & 0.179 \\
\hline \multicolumn{5}{|c|}{ Should students be educated about FGM/C?, $n(\%)$} \\
\hline Yes & $81(71.7)$ & $180(69.8)$ & 37.552 & $<0.001$ \\
\hline No & $32(28.3)$ & $78(30.2)$ & 19.236 & $<0.001$ \\
\hline \multicolumn{5}{|l|}{ At what level in school?, $n(\%)$} \\
\hline Primary & $24(21.2)$ & $78(30.2)$ & 28.588 & 0.003 \\
\hline Secondary & $53(46.9)$ & $96(37.2)$ & 12.409 & $<0.001$ \\
\hline Tertiary & $4(3.5)$ & $6(2.3)$ & 0.400 & 0.527 \\
\hline \multicolumn{5}{|c|}{ Have you ever educated students about FGM/C?, $n(\%)$} \\
\hline Yes & $23(20.4)$ & $46(17.8)$ & 7.667 & 0.005 \\
\hline No & $90(79.6)$ & $212(82.2)$ & 49.285 & $<0.001$ \\
\hline
\end{tabular}

$p=0.220$ ), knew the correct definition of FGM/C $(199$ v. $81 ; p<0.001)$ and were taught about awareness and implications of FGM/C as students ( 80 v. $37 ; p=0.001$ ). Also, 20 males (17.7\%) and 44 females (17.1\%) were educated about FGM/C in secondary school, 180 females $(69.8 \%)$ and 81 males $(71.7 \%)$ wanted students to be taught about awareness and implications of FGM/C in schools, and 46 females (17.8\%) and 23 males (20.4\%) had educated students about FGM/C.

Table 2 shows that 109 (42.2\%) of the female teachers had been mutilated, at a mean (SD) age of 4.76 (4.86) years. Of these procedures, 49 (45.0\%) were performed by traditional circumcisers and $35(32.1 \%)$ by medical personnel.

Among the 50 men and 159 women who had daughters at the time of the interview, 22 males (44.0\%) and 39 females (24.5\%) had subjected their daughters to FGM/C $(p=0.029)$, mainly for religious reasons. Male teachers were the major initiators of FGM/C for their daughters $(9,40.9 \%)$ while mothersin-law were responsible among the female teachers $(16,41.0 \%)$, as shown in Table 3.

Views about FGM/C and its eradication are shown in Table 4: 44 females (17.1\%) and

Table 2. Experience of female teachers who had undergone FGM/C $\left(N=109^{*}\right)$

\begin{tabular}{|c|c|}
\hline \multicolumn{2}{|l|}{ Variables } \\
\hline $\begin{array}{l}\text { Age when mutilated/ } \\
\text { circumcised (years), mean (SD) }\end{array}$ & $4.76(4.86)$ \\
\hline \multicolumn{2}{|l|}{ Who performed it?, $n(\%)$} \\
\hline Medical personnel & $35(32.1)$ \\
\hline Doctor & $16(14.7)$ \\
\hline Nurse & $19(17.4)$ \\
\hline Religious leader & $7(6.4)$ \\
\hline Older woman & $18(16.5)$ \\
\hline Traditional circumciser & $49(45.0)$ \\
\hline \multicolumn{2}{|l|}{$\begin{array}{l}\text { Describe your experience, } \\
n(\%)\end{array}$} \\
\hline Painful & $44(40.4)$ \\
\hline Lost much blood & $4(3.7)$ \\
\hline Enjoyed it & $3(2.8)$ \\
\hline Cannot remember & $58(53.2)$ \\
\hline \multicolumn{2}{|l|}{$\begin{array}{l}\text { Feeling when you remember } \\
\text { you were circumcised, } n(\%)\end{array}$} \\
\hline Happy/satisfied & $30(27.5)$ \\
\hline Proud of it & $20(18.3)$ \\
\hline Hated it & $26(23.9)$ \\
\hline Do not know & $33(30.3)$ \\
\hline
\end{tabular}


Table 3. Experience of teachers whose daughters had undergone FGM/C*

\begin{tabular}{|c|c|c|c|c|}
\hline Variables & $\begin{array}{l}\text { Male } \\
(N=22) \\
n(\%)\end{array}$ & $\begin{array}{l}\text { Female } \\
(N=39) \\
n(\%)\end{array}$ & $\chi^{2}$ & $p$-value \\
\hline \multicolumn{5}{|l|}{ Place where FGM/C was performed } \\
\hline Home & $9(40.9)$ & $12(30.8)$ & 0.429 & 0.512 \\
\hline Hospital & $9(40.9)$ & $13(33.3)$ & 0.727 & 0.393 \\
\hline Traditional herbalist at home & $4(18.2)$ & $11(28.2)$ & 3.267 & 0.070 \\
\hline Others & $0(0.0)$ & $3(7.7)$ & 3.000 & 0.083 \\
\hline \multicolumn{5}{|l|}{ Reason for FGM/C } \\
\hline Religion & $14(63.6)$ & $21(53.8)$ & 1.400 & 0.236 \\
\hline Cultural & $5(22.7)$ & $10(25.6)$ & 1.667 & 0.196 \\
\hline Pressure from others & $0(0.0)$ & $1(2.6)$ & 1.000 & 0.317 \\
\hline Because I was circumcised & $1(4.6)$ & $5(12.9)$ & 2.667 & 0.102 \\
\hline Other girls were circumcised too & $2(9.1)$ & $2(5.1)$ & 0.000 & 1.000 \\
\hline \multicolumn{5}{|l|}{ Daughter's experience } \\
\hline Painful & $11(50.0)$ & $20(51.3)$ & 2.613 & 0.105 \\
\hline Lost a lot of blood & $0(0.0)$ & $3(7.7)$ & 3.000 & 0.083 \\
\hline No problem & $10(45.4)$ & $15(38.4)$ & 1.000 & 0.317 \\
\hline Cannot remember & $1(4.6)$ & $1(2.6)$ & 0.000 & 1.000 \\
\hline \multicolumn{5}{|c|}{$\begin{array}{l}\text { Parent's feeling on remembering daughter underwent } \\
\text { FGM/C }\end{array}$} \\
\hline Happy/satisfied & $13(59.1)$ & $22(56.4)$ & 2.314 & 0.128 \\
\hline Proud of it & $2(9.1)$ & $3(7.7)$ & 0.200 & 0.654 \\
\hline Regretted it & $0(0.0)$ & $2(5.1)$ & 2.000 & 0.157 \\
\hline Hated it & $2(9.1)$ & $6(15.4)$ & 2.000 & 0.157 \\
\hline Do not know & $5(22.7)$ & $6(15.4)$ & 0.000 & 1.000 \\
\hline \multicolumn{5}{|l|}{ Initiator of daughter's circumcision } \\
\hline Myself & $9(40.9)$ & $9(23.1)$ & 0.000 & 1.000 \\
\hline Husband & $1(4.5)$ & $5(12.9)$ & 2.667 & 0.102 \\
\hline My mother & $6(27.2)$ & $4(10.3)$ & 0.400 & 0.527 \\
\hline Mother-in-law & $1(4.6)$ & $16(41.1)$ & 13.235 & $<0.001$ \\
\hline Relatives/friends & $1(4.6)$ & $1(2.6)$ & 0.000 & 1.000 \\
\hline Others & $4(18.2)$ & $4(10.3)$ & 0.00 & 1.000 \\
\hline \multicolumn{5}{|c|}{ Did you agree when your daughter was circumcised? } \\
\hline Yes & $18(81.8)$ & $31(79.5)$ & 3.449 & 0.063 \\
\hline No & $4(18.2)$ & $8(20.5)$ & 1.333 & 0.248 \\
\hline
\end{tabular}

23 males (20.4\%) supported continuation of FGM/C, 71 males (62.8\%) and 195 females (75.6\%) agreed with government efforts to eradicate FGM/C, and 28 males (24.8\%) and 51 females (19.8\%) indicated that they would circumcise their future daughters. The male teachers suggested partnership with religious leaders $(n=27,23.9 \%)$, while female teachers suggested education $(n=54,21.0 \%)$ as the top priority interventions to stop FGM/C.

Table 5 shows that the predictors of the likelihood of participants (whole study population) supporting discontinuation of FGM/C had undergone FGM/C (OR 12.688; 95\% CI 2.791 - 57.673; $p=0.001$ ).

\section{Discussion}

In this study, about a third of the teachers had been made aware of and taught about the implications of FGM/C while they were at school, but the majority had never educated their students, although they held the opinion that its awareness and implications should be taught in schools. The prevalence rate of FGM/C among female teachers was $42.3 \%$; a quarter of the female and about half of male teachers had circumcised their daughters, mainly for religious reasons. The male teachers were the major initiators of $\mathrm{FGM} / \mathrm{C}$ for their daughters, while among the female teachers the mothers-in-law were responsible. Most teachers felt that education and legislation were possible interventions towards eradication of FGM/C.

Strengths of the study are the evaluation of teachers in both rural and urban areas, and relating their knowledge to their views, attitude and practice. Limitations include the fact that mutilation of female teachers was selfreported without physical verification, and the challenge of recall of their age at the time of mutilation.

Knowledge about FGM/C among participants in this study was higher than the national averages of $68 \%$ (women) and $62 \%$ (men) ${ }^{[5]}$ The reported prevalence of FGM/C among female teachers in this study was higher than the national prevalence rate of $25 \%$ among women in Nigeria, ${ }^{[5]}$ but lower than the average rate of $33 \%$ for women in West Africa. ${ }^{[6]}$ This may be because participants were educated, which offers the opportunity for social networks and a higher level of knowledge about FGM/C and may have contributed to their disclosure. The mean age at which they had suffered genital mutilation reported by women in this study was similar to the report of $<5$ years in most countries ${ }^{[7]}$ and $83.2 \%$ of FGM/C before age 5 in the study locality. ${ }^{[5]}$ Traditional circumcisers performed the highest proportion of FGM/C among female teachers in this study, similar to reports from most countries where it is performed, ${ }^{[7]}$ but lower than the national average of $80 \%$ involvement of traditional circumcisers in Nigeria. ${ }^{[5]}$ Traditional circumcisers are usually lay men with little or no knowledge of human anatomy ${ }^{[8]}$ who 
Table 4. Views of teachers about FGM/C and its eradication

\begin{tabular}{|c|c|c|c|c|}
\hline Variables & $\begin{array}{c}\text { Male } \\
n(\%)\end{array}$ & $\begin{array}{l}\text { Female } \\
n(\%)\end{array}$ & $\chi^{2}$ & $p$-value \\
\hline \multicolumn{5}{|l|}{ Should females be circumcised? } \\
\hline Yes & $23(20.4)$ & $44(17.0)$ & 6.582 & 0.010 \\
\hline No & $47(41.6)$ & $146(56.6)$ & 50.782 & $<0.001$ \\
\hline I don’t know & $43(38.0)$ & $68(26.4)$ & 5.631 & 0.017 \\
\hline \multicolumn{5}{|l|}{ Participant description of FGM/C } \\
\hline Wickedness against women & $46(40.7)$ & $140(54.3)$ & 47.505 & $<0.001$ \\
\hline Old fashioned & $42(37.2)$ & $77(29.8)$ & 10.294 & 0.001 \\
\hline Good for girls & $18(15.9)$ & $25(9.7)$ & 1.140 & 0.285 \\
\hline Makes a girl a real woman & $7(6.2)$ & $16(6.2)$ & 3.522 & 0.060 \\
\hline \multicolumn{5}{|l|}{ Do you know any benefits of FGM/C? } \\
\hline Yes & $19(16.8)$ & $38(14.7)$ & 6.333 & 0.011 \\
\hline No & $94(83.2)$ & $220(85.3)$ & 50.561 & $<0.001$ \\
\hline \multicolumn{5}{|c|}{ Awareness of government effort to stop FGM/C } \\
\hline Yes & $65(57.5)$ & $175(67.8)$ & 50.417 & $<0.001$ \\
\hline No & $48(42.5)$ & $83(32.2)$ & 9.351 & 0.002 \\
\hline \multicolumn{5}{|l|}{ Do you agree with this government effort? } \\
\hline Yes & $71(62.8)$ & $195(75.6)$ & 57.805 & $<0.001$ \\
\hline No & $42(37.2)$ & $63(24.4)$ & 4.200 & 0.040 \\
\hline \multicolumn{5}{|l|}{ What are your suggestions to stop FGM/C? } \\
\hline Education & $25(22.1)$ & $54(21.0)$ & 10.646 & 0.001 \\
\hline Appeal to parents & $17(15.1)$ & $53(20.5)$ & 18.514 & $<0.001$ \\
\hline Radio/TV announcements & $18(15.9)$ & $50(19.4)$ & 15.059 & $<0.001$ \\
\hline Law and punishment & $25(22.1)$ & $40(15.5)$ & 3.462 & 0.062 \\
\hline Arrest parents who circumcise & $1(0.9)$ & $8(3.1)$ & 5.444 & 0.019 \\
\hline Partner with religious leaders & $27(23.9)$ & $53(20.5)$ & 8.450 & 0.003 \\
\hline \multicolumn{5}{|c|}{ If you have another daughter, will you circumcise her? } \\
\hline Yes & $28(24.8)$ & $51(19.8)$ & 6.696 & 0.009 \\
\hline No & $85(75.2)$ & $207(80.2)$ & 50.973 & $<0.001$ \\
\hline \multicolumn{5}{|l|}{ Compare male and female circumcision } \\
\hline Both are good & $24(21.2)$ & $32(12.4)$ & 1.143 & 0.285 \\
\hline Female circumcision good, male bad & $1(0.9)$ & $3(1.2)$ & 1.000 & 0.317 \\
\hline Male good, female bad & $65(57.5)$ & $185(71.7)$ & 57.600 & $<0.001$ \\
\hline Both are bad and should be stopped & $8(7.1)$ & $12(4.6)$ & 0.800 & 0.371 \\
\hline Do not know & $15(13.3)$ & $26(10.1)$ & 2.951 & 0.085 \\
\hline
\end{tabular}

also play a central role in the community, such as attending to childbirth. ${ }^{[2]}$

Medicalisation of FGM/C refers to its practice by any category of healthcare provider, whether in a public or private clinic, at home or elsewhere. ${ }^{[9]}$ Generally, FGM/Cs by health workers range from $<1 \%$ to between $9 \%$ and $74 \% ;{ }^{[9]}$ the $32.1 \%$ in this study was higher than national average of $12-13 \%$ in Nigeria, ${ }^{[5]}$ while the World Health Organization (WHO) reported medicalisation in over $18 \%$ of cases. ${ }^{[2]}$ Increasing trends in medicalisation have been documented by the WHO despite the ban on the act, ${ }^{[10]}$ and this may make its eradication difficult. ${ }^{[1,9]}$
The majority of the teachers wanted awareness and implications of FGM/C to be taught in schools, similar to the United Nations Children's Fund (UNICEF) recommendation to create opportunity for discussion locally and internationally about the act. ${ }^{[7]}$ However, this was not a predictor of support for its discontinuation, perhaps reflecting the interplay between social, moral and legal norms on FGM/C for which the social may dominate, thereby blunting the expected influence.

Religious obligation was the indication for $\mathrm{FGM} / \mathrm{C}$ in more than half of the teachers who circumcised their daughters, unlike the National Demographic Health Survey 2013, which showed that religion was not a major indication in Nigeria. ${ }^{[5]}$ This buttresses the debate around religion and $\mathrm{FGM} / \mathrm{C}$, as no religion requires it, but all religious groups practise it. ${ }^{[8]}$

Many participants in this study viewed FGM/C as wickedness against women ( $40.7 \%$ of men and $54.3 \%$ of women), similar to its designation as violence against women by UNICEF. In this study, $80.2 \%$ of female teachers expressed the desire not to circumcise their future daughters, similar to $62 \%$ of women in a previous study in Nigeria. ${ }^{[7]}$ This suggests increasing support among women regarding eradication of the act.

A major concern from this study is that male teachers whose daughters had undergone FGM/C were the major initiators and supporters of the act. This brings to the fore the dominant role of men in decision-making about the health matters of women and girls. This is prevalent in Africa and other maledominated cultures, and reportedly stems from deep-rooted inequality between the sexes. ${ }^{[2]}$ This is important, since male teachers are central in addressing eradication of FGM/C.

In addition, the role of mothers-in-law as the initiators and major supporters of FGM/C and its continuation corroborates an earlier report that older women are sometimes unwilling to give up the practice, and may be major propagators of the act. ${ }^{[1]}$

The disparity in information, view, practice and belief among about 20\% of the teachers expressing their resolve to circumcise their future daughters calls for a social movement within a broader social context to be strengthened by legislation, ${ }^{[1]}$ education, partnership with religious leaders, parents and information on the mass media.

In Nigeria there is no legislation at national level except in a few states, ${ }^{[1]}$ excluding the study locality. With $11 \%$ of girls and women with FGM/C living in Nigeria alone, ${ }^{[10]}$ it is imperative to explore all possibilities to eradicate the act.

Although it has been documented that there was a reduction of $1 \%$ per year in FGM/C globally between 2005 and 2010, ${ }^{[6]}$ this has been shown to be inadequate to achieve its eradication. Reports have also shown that FGM/C has continued despite strict legislation against it, ${ }^{[12]}$ emphasising the need for other supportive interventions. 


\begin{tabular}{llll}
$\begin{array}{l}\text { Table 5. Logistic regression predicting likelihood of participant agreeing that } \\
\text { FGM/C should be stopped }\end{array}$ & \multicolumn{1}{l}{ p-value } & OR & $\mathbf{9 5 \%}$ CI \\
\hline Variables & & & \\
\hline Whole study population & 0.196 & 1.664 & $0.769-3.559$ \\
$\quad$ Gender & 0.009 & 0.315 & $0.133-0.747$ \\
Heard about FGM/C & 0.474 & 0.751 & $0.342-1.646$ \\
Correct knowledge of FGM/C & 0.080 & 1.935 & $0.925-4.047$ \\
Was educated on FGM/C as student & 0.001 & 3.887 & $1.852-8.159$ \\
Daughter has undergone FGM/C & 0.002 & 0.307 & $0.148-0.636$ \\
Aware of government policy to stop FGM/C & & & \\
Female teachers only & 0.003 & 0.230 & $0.087-0.609$ \\
Heard about FGM/C & 0.138 & 0.499 & $0.199-1.249$ \\
Correct knowledge of FGM/C & 0.099 & 2.166 & $0.864-5.431$ \\
Was educated on FGM/C as student & 0.182 & 0.436 & $0.129-1.477$ \\
Has undergone FGM/C & 0.127 & 2.111 & $0.808-5.518$ \\
Daughter has undergone FGM/C & 0.001 & 0.204 & $0.087-0.476$ \\
Aware of government policy to stop FGM/C & & & \\
Male teachers only & 0.724 & 0.661 & $0.066-6.587$ \\
Heard about FGM/C & 0.259 & 3.050 & $0.440-21.153$ \\
Correct knowledge of FGM/C & 0.156 & 3.102 & $0.649-14.834$ \\
Was educated on FGM/C as student & 0.001 & 12.688 & $2.791-57.673$ \\
Daughter has undergone FGM/C & 0.892 & 0.886 & $0.156-5.031$ \\
Aware of government policy to stop FGM/C & & & \\
& & &
\end{tabular}

A practice guideline ${ }^{[13]}$ in the UK has indicated a vital role for teachers in eradication of FGM/C. It recommends a central role for teachers who are likely to be approached by girls under threat of FGM/C or their friends who may be aware of the threat. They may also recognise indicators such as absenteeism, a sudden
In conclusion, this study shows that although secondary schoolteachers have a role in eradication of FGM/C, they are currently illequipped to perform this role. We recommend efforts to raise awareness about the dangers and human rights abuses of FGM/C among teachers, produce and circulate appropriate information materials, and use reorientation and motivation to encourage their effectiveness as agents for FGM/C eradication.

1. UNICEF. Female Genital Mutilation/Cutting: A Statistical Overview and Exploration of the Dynamics of Change. New York: UNICEF, 2013. http://www.unicef.org/publications/ index_69875.html (accessed 10 October 2014).

2. WHO. Female Genital Mutilation. Fact sheet No. 241; updated February 2014. http://www.who.int/mediacentre/factsheets/ fs241/en/ (accessed 11 March 2015).

3. The Point: Gambia News For Freedom and Democracy Circumcisers from Kombo South Trained on FGM and Right of Women and Children. 22 December 2010. www.fgcblogger (accessed 24 September 2012).

4. Araoye MO. Research Methodology with Statistics for Health and Social Sciences. Ilorin: Nathadex Press, 2003:115-121.

5. National Population Commission (Nigeria). Nigeria Demographic and Health Survey (2013). Abuja: NPC, 2014.

6. UNFPA. Projections of number of young girls ages 15-19 who will experience FGM/C from 2010-2030. UNFPA, 2013. http:// www.unfpa.org/public (accessed 20 May 2014).

7. UNICEF. Female Genital Mutilation/Cutting: A Statistical Overview and Exploration of the Dynamics of Change. New York: UNICEF, 2013 http://data uniceforg/child-protection/ fgmc (accessed 20 December 2013).

Althaus FA. Female circumcision: Rite of passage or violation of rights? Int Fam Plann Perspective 1997;23(3):130-133.

9. World Health Organization. Global strategy to stop healthcare providers from performing female genital mutilation. UNFPA, UNHCR, UNICEF, UNIFEM, WHO, FIGO, ICN, IOM, MWIA, WCPT, WMA. Geneva: WHO; 2010. http:// www.int/reproductivehealth/publications/fgm/rhr_10_9/en/ index.html (accessed 12 August 2014).

10. World Health Organization. An Update on WHO's Work on Female Genital Mutilation (FGM): Progress Report. Geneva: WHO, 2011. http://www.who.int/en/ (accessed 10 Augus 2014).

11. UNFPA. A Holistic Approach to the Abandonment of Female Genital Mutilation/ Cutting. New York: UNFPA, 2007. http:// www.unfpa.org/public/ (accessed 1 February 2013).

12. Tanzania: How to eradicate FGM. www.fgcblogger (accessed 24 September 2012)

13. Multi-Agency Practice Guideline. Female Genital Mutilation. www.gov.uk (accessed 25 January 2015). 